\title{
Ortaokul öğrencilerinin Türkçe dersinde kullandıkları eleştirel dinleme stratejilerinin çeşitli değişkenler yönünden incelenmesi ${ }^{1}$
}

\section{Mehmet FİDAN²}

\begin{abstract}
APA: Fidan, M. (2019). Ortaokul öğrencilerinin Türkçe dersinde kullandıkları eleştirel dinleme stratejilerinin çeșitli değişkenler yönünden incelenmesi. RumeliDE Dil ve Edebiyat Araștırmalar Dergisi, (15), 79-98. DOI: 10.2900o/rumelide.580463
\end{abstract}

Özet

Dinleme eğitimi çok boyutlu yapısı ile eğitim-öğretim süreçlerinde önemli konumda bulunur. Dinleme eğitimi süreçlerinde öğrencilerin kullandıkları stratejilerinden olan eleştirel dinleme öğrencinin akademik gelişimini olumlu yönde şekillendirmektedir. Bu sebeple öğrencilerin derslerde kullandıkları eleştirel dinleme stratejilerinin belirlenmesi gerekmektedir. Bu araştırmada, ortaokul öğrencilerinin Türkçe derslerinde kullandıkları eleştirel dinleme stratejilerinin değerlendirilmesi yapılmıştır. Araştırma sürecinde nicel araştırma yöntemlerinden tarama modeli kullanılmıştır. Öğrencilerin Türkçe derslerinde kullandıkları eleştirel dinleme stratejileri cinsiyet, sınıf düzeyi ve sosyo-ekonomik düzey yönünden karşılaştırmalı olarak incelenmiştir. Ayrıca öğrencilerin eleştirel dinleme stratejilerini kullanım oranları belirlenmeye çalışılmıştır. Araştırmanın çalışma evreni Kayseri ili Melikgazi, Talas ve Kocasinan ilçelerindeki ortaokul öğrencilerinden oluşmuştur. Araştırmanın örneklemi bu öğrenciler arasından random örnekleme yöntemi ile seçilen öğrencilerden oluşmaktadır. Araştırmada F testi (tek yönlü varyans analizi), derecelendirme analizi (yüzde, frekans) ve $\mathrm{t}$ - testi kullanılmıştır. Araştırma sonucunda maddelerin genel ortalamasına bakıldığında, öğrencilerin eleştirel dinleme stratejilerini kullanımlarının cinsiyet, sınıf düzeyi, sosyoekonomik düzey yönünden bazı maddelerde farklılaştığı görülmüştür. Öğrencilerin genel olarak eleştirel dinleme stratejilerini kullandıkları sonucuna ulaşılmıştır. Bu duruma ek olarak, öğrencilerin Türkçe derslerinde dinlediklerini önem sırasına koyma stratejisini diğer eleştirel dinleme stratejilere göre daha az kullandıkları tespit edilmiştir.

Anahtar kelimeler: Dinleme becerisi, dinleme stratejileri, eleştirel dinleme stratejileri.

\section{Examination of critical listening strategies in Turkish lessons of secondary school students in terms of various variables}

\begin{abstract}
Listening education is very important in education processes with its multi-dimensional structure. The critical listening which is one of the strategies used by students in listening education processes positively shape the academic development of the students. For this reason, students' critical listening strategies should be determined. In this study, the critical listening strategies used by secondary school students in Turkish lessons were evaluated. In the research process, the screening model was used. The critical listening strategies used by the students in Turkish lessons were examined in terms of gender, class level and socio-economic level. In addition, the use of critical
\end{abstract}

$\mathrm{Bu}$ çalışma "İlköğretim İkinci Kademe Öğrencilerinin Türkçe Dersinde Kullandıkları Dinleme Stratejilerinin Değerlendirilmesi” isimli yüksek lisans tezinden yararlanılarak üretilmiştir.

2 Dr. Öğr. Üyesi, Aksaray Üniversitesi, Eğitim Fakültesi, Türkçe ve Sosyal Bilimler Bölümü (Aksaray / Türkiye), fidanm3838@gmail.com, ORCID ID: 00oo-0002-9347-2992 [Makale kayit tarihi: 21.03.2019-kabul tarihi:16.06.2019; DOI: $10.29000 /$ rumelide.580463] 
Examination of critical listening strategies in Turkish lessons of secondary school students in terms of various variables / M. Fidan (p. 79-98)

\begin{abstract}
listening strategies of students was tried to be determined. The study population of the study was composed of middle school students in Kayseri, Melikgazi, Talas and Kocasinan districts. The sample of the study consisted of randomly selected students. F test (one way variance analysis), rating analysis (percentage, frequency) and $t$ - test were used in the study. As a result of the research, it is seen that the use of critical listening strategies of the students differed in terms of gender, class level, socio-economic level. It is concluded that students generally use critical listening strategies. In addition to this situation, it is determined that the students use less than the other critical listening strategies in order to rank the importance to what they listening in Turkish lessons.
\end{abstract}

Keywords: Listening skills, listening strategies, critical listening strategies.

\title{
Giriş
}

Sağlıklı bireylerde ilk kazanılan dil becerisi olan dinleme, çok boyutlu yapısı ile önemli konumda bulunmaktadır. Bireylerin hem anlamlandırma hem de ifade edebilme kabiliyetleri dinleme becerisinin gelişimine bağlı olarak şekillenmektedir. Nitekim anlamlandırma davranışının doğumdan itibaren başladığına yönelik çalışmalar bulunmaktadır. Bu dönemde işitme, koku alma, temas vasıtasıyla duyu organları bireylerin çevrelerini anlamlandırmalarını sağlamaktadır. Bu konuyla ilgili olarak Cüceloğlu (2010: 343) "Çocuk, doğduğundan 6 saat sonra hipokampusta, o örtük bellekte anlam verme sistemini geliştirmeye başlıyor ve değerler de anlam verme sisteminin bir parçası olarak daha korteks gelişmeden önce duygusal yaşamla birlikte gelişmeye başlıyor." şeklinde açıklama yapar. Bu durum dinleme-anlama ilişkisinin belirlenmesi açısından önemlidir.

Dinleme, ilk kazanılan dil becerisi olmasının yanında toplumsal normlar yönünden de önemli konumda bulunmaktadır. Uzun bir tarihi ve kültürel geçmişi yapısında barındıran atasözleri toplumsal algıları ve değerleri yansıtır. Dinleme ile ilgili atasözleri bu becerinin toplumsal açıdan karşılığının tespit edilmesine yardımcı olmaktadır. Bu konuyla ilgili olarak Gürel ve Tat (2012:280) araştırmalarında " $A z$ söyle çok dinle, Bir söyle on dinle, İki kulak bir dil için, Söyleyenden dinleyen arif gerek, Tath söz dinletir, tatsız söz esnetir" gibi atasözlerinin dinleme ile ilişkili olduğunu belirtirler. Bu durum dinlemenin toplumsal açıdan rolünü ortaya koymaktadır.

Genelde informal öğrenmeler vasıtasıyla kazanılan dinleme becerisi, diğer dil becerilerinin de üzerine temellendiği bir yapıda bulunmaktadır. Nitekim konuşma becerisinin gelişimi dinleme becerisinin varlığına bağlı olarak gelişim göstermektedir. Doğan (2012:3), dinleme ve konuşma becerilerinin birbirleri ile yakın bağlarının olduğunu, konuşma olabilmesi için dinlemenin gerekli olduğunu belirtir. Çünkü bireylerin kendilerini etkili bir biçimde ifade edebilmeleri, aynı zamanda çevrelerini iyi bir biçimde algılayabilmelerini ve anlamlandırmalarını gerektirmektedir. Bu anlamlandırma süreçlerinde de dinleme, en çok kullanılan dil becerilerinden biri olarak öne çıkar.

Dinleme hem eğitsel gelişim hem de sosyal ilişkiler açısından önemlidir. Bireylerin sosyal yaşamlarında dinleme, diğer dil becerilerine göre daha etkin konumda yer almaktadır. Bireylerin sosyal ilişkilerine ayırdıkları vakitlerin "\%42'sini dinlemekle geçirdiği”, dinlemenin akademik başarıyı etkilediği araştırmacılar tarafindan belirtilmektedir (Göğüş, 1978: 227; akt. Sever, 2011:11). Bu duruma ek olarak araştırmalar okulda öğrencilerin genelde dinleme/izleme davranışını gösterdiğini, dinlemenin öğrenmede etkili olduğunu ortaya koymaktadır (Aktaş ve Gündüz, 2017:87). 
Dinleme becerisinin diğer dil becerilerinin gelişimini etkilemesi ana dil eğitiminde de bu becerilerin geliştirilmesine yönelik çalışmaları zorunlu kılmaktadır. Bu amaçla geliştirilen eğitim-öğretim programlarında dinleme, öncelikli dil becerisi olarak görülür. Nitekim birçok öğretim yöntemi dinleme temelli olarak uygulanmaktadır. Bu konuyla ilgili olarak Gücüyeter (2009:169) ders başarısının sağlanmasında etkili dinleme becerisinin geliştirilmesinin bir ön şart olduğunu belirtir. Bu becerinin yalnızca dinleme metinlerinde kullanılmadığının ve eğitim-öğretim süreçlerinin genelinde etkin olduğunun bilinmesi öğrencilerin gelişimlerine olumlu etkide bulunacaktır.

\section{Dinleme eğitimi}

Toplum yaşamında hem genel hem de bireysel manada uyumun sağlanmasında dil becerileri önemli konumda bulunmaktadır. Bu amaçla eğitim-öğretim çağının başlangıcından itibaren bireylere verilen ana dili eğitimleri bireysel gelişimin yanında millî, kültürel ve evrensel değerlerin gelişimini de temel almaktadır. Ana dili eğitiminin yapısal niteliği incelendiğinde Türkçe Dersi Öğretim Programı’nda dinleme, okuma, konuşma ve yazma becerilerine yer verildiği görülür (MEB:2018). Bu programın özel amaçları arasında “dinleme/izleme, konuşma, okuma ve yazma becerilerinin geliştirilmesi” öncelikli bir konumda bulunmaktadır (MEB, 2018, 8). Bu becerilerden olan dinleme/izlemeye Türkçe Dersi Öğretim Programı'nın bütün sınıf düzeylerinde ilk kazanım başlığı olarak yer verilmesi eğitsel hedefler açısından dinlemenin rolünü ortaya koymaktadır.

Dinleme eğitiminin bütüncül bir yapıda olması bu beceri ile ilgili çalışmalarda araştırmacılara geniş imkânlar sunmaktadır. Dinlemenin fizyolojik, zihinsel, psikolojik, sosyal yapısının da bulunması alan araştırmacılarının bu konuya odaklanmalarını sağlamıştır. Bu konuyla ilgili yapılan çalışmalar genel olarak incelendiğinde dinleme ile diğer dil becerilerinin ilişkisi, dinlemenin zihinsel gelişimdeki rolü gibi konularda araştırmaların yoğun olduğu görülmektedir. Doğan ve Özçakmak (2014:97) dinleme eğitimi alanındaki çalışmaların sayısının son yıllarda giderek arttığını, bu çalışmaların özellikle 20092013 yılları arasında yoğunlaştığını tespit ederler. Epçaçan (2013:343) öğrencilerin dinleme becerilerinin geliştirilmesine etkinlik temelli dinleme uygulamalarının olumlu katkısının olduğunu belirtir. Doğan (2008:278) yaptığı deneysel çalışma vasıtasıyla dinleme becerisinin eğitsel yöntemlerle geliştirilebileceği sonucuna ulaşır. Kurudayıŏ̆lu ve Kana (2013:245) araştırmalarında "Türkçe öğretmeni adaylarının dinleme eğitimi ve dinleme becerisi özyeterlik algılarının” olduğunu tespit ederler. Katrancı ve Yangın (2013:754-755) "Üstbiliş Stratejileri Öğretiminin Dinlediğini Anlama Becerisine ve Dinlemeye Yönelik Tutuma Etkisi” başlıklı araştırmalarında, üst biliş stratejisinin geliştirmesine yönelik çalışmaların dinlediğini anlama becerisinin gelişimine olumlu yönde etkide bulunduğu sonucuna ulaşmışlardır. Melanlığlu (2012:1593), üstbiliş stratejilerinin dinleme eğitimindeki ölçme-değerlendirme çalışmalarında kullanımını incelediği araştırmasında dinlemenin "içsel bir süreç olarak değerlendirilmesi" gerektiğini belirtir ve "dinleme farkındalığı", "kendi kendini değerlendirme" konularına dikkat çeker.

\section{Dinleme stratejileri}

Öğrencilerin dinleme becerilerinin geliştirilmesinde ve dinleme etkinliklerinden en üst düzeyde verim alabilmek için derslerde kullanılan dinleme stratejileri önemli konumda bulunmaktadır. Bireylerin dersin kazanımları, kendilerinin ilgi ve ihtiyaçları doğrultusunda geliştirecekleri (kullanacakları) dinleme stratejileri eğitsel amaçlara ulaşılmasına yardımcı olmaktadır. Araştırmacıların dinleme stratejileri ile ilgili sınıflandırmaları incelendiğinde "bilişsel, duyuşsal, beden diliyle ilgili stratejiler", "dinleme öncesi, dinleme sırası, dinleme sonrası stratejiler”, "parçadan bütüne, bütünden parçaya, üst 
Examination of critical listening strategies in Turkish lessons of secondary school students in terms of various variables / M. Fidan (p. 79-98)

bilişsel stratejiler", "ayrıştırıcı, iletişimsel, estetik, bilgi için stratejiler, eleştirel stratejiler" gibi farklı gruplandırmaların olduğu görülmektedir (Fidan, 2012: 34-35). Yılmaz (2007: 38-40) "Türkçe Öğretiminde Dinleme Becerisini Geliştirmeye Yönelik Önerilen Etkinliklerin Değerlendirilmesi” isimli araştırmasında dinleme yöntemlerini "katılımlı, katılımsız, not alarak, grup halinde, yaratıcı, seçici, eleştirel dinleme” başlıkları altında sıralar. MEB Türkçe Dersi Öğretim Programı'nda kazanım olarak yer alan dinleme stratejilerini şu şekilde sıralamak mümkündür:

"Dinlerken nezaket kurallarına uyma, dikkatini dinlediğine yoğunlaştırma, not alarak dinleme, katılıml dinleme, katılımsız dinleme, grup halinde dinleme, empati kurarak dinleme, seçici dinleme, yaratıcı dinleme, eleştirel dinleme" (MEB, 2018: 21-48).

Eleştirel dinleme becerisi bireylerin üstbilişsel düşünme becerilerini kullandıkları bir alan olarak ön plana çıkmaktadır. Nitekim Umagan (2007:154) da eleştirel dinlemenin üstbilişsel düşünme basamağ olan değerlendirmeyi oluşturduğunu ifade eder ve bunu "dinlediklerinin doğruluğunu kontrol etme çabası" olarak tanımlar. Aktaş ve Gündüz (2017:92) eleştirel dinlemeyi, "dinlediğini sebep-sonuç ilişkisi kurarak doğruluk, eksiklik vb. bakımından değerlendirmektir” şeklinde tanımlamaktadır. Akyol (2014:14-15) ise eleştirel dinlemenin "transfer edici dinlemenin bir ileri boyutu" olduğunu ifade eder ve "eleştirel dinleme çerçevesinde ikna ve propaganda edici konuşma etkinliklerini” ele alır. Akyol (2014:18-19) eleştirel dinleme öğretim çalışmalarında "reklamın tanıtımı, aldatıcı dilin açıklanması, aldatıcı dilin analiz edilmesi, kavramların gözden geçirilmesi, alıştırma çalışmaları, öğrencilere reklam hazırlatma" uygulamalarının yapılabileceğini belirtir. Bu durum araştırmacının eleştirel dinlemenin sadece sınıfla sınırlı olmadığını, gerçek hayata aktarılması gerekliliğini düşündüğünü göstermektedir.

\section{Yöntem}

Araştırmanın bu bölümünde araştırmanın örneklemi, verilerin toplanma biçimleri, ölçme araçları ve verilerin analiz edilmesi yer almaktadır. Araştırma sorularını şu şekilde sıralamak mümkündür:

Ortaokul öğrencilerinin eleştirel dinleme stratejilerini kullanma oranları nedir?

Eleştirel dinleme stratejileri sınıf düzeyi yönünden değişkenlik gösteriyor mu?

Eleştirel dinleme stratejileri cinsiyet yönünden değişkenlik gösteriyor mu?

Eleştirel dinleme stratejileri sosyo-ekonomik düzey yönünden değişkenlik gösteriyor mu?

\section{Araştırmanın modeli}

Ortaokul öğrencilerinin Türkçe derslerinde kullandıkları eleştirel dinleme stratejilerinin değerlendirilmesinin amaçlandığı bu çalışmada nicel araştırma yöntemlerinden tarama modeli kullanılmıştır. Öğrencilerin derslerde kullandıkları dinleme stratejilerinin belirlenebilmesi için likert tipi dinleme stratejileri ölçeği tercih edilmiştir. Sonuçlar eleştirel dinleme stratejilerinin kullanım oranları, sınıf düzeyi, sosyo-ekonomik durum ve cinsiyet değişkenleri açısından analiz edilmiştir. Eleştirel dinleme stratejilerinin oransal yönden analizinde yüzdelik dilim hesabı göz önünde bulundurulurken, stratejilerin değişkenler yönünden incelenmesinde $(\mathrm{p}<0,05)$ gruplar arasındaki anlamlı farklılık ölçüt olarak kabul edilmiştir.

\section{Örneklem}

$\mathrm{Bu}$ araştırmanın çalışma evreni Kayseri ili Melikgazi, Kocasinan, Talas ilçelerindeki ortaokullarda öğrenim gören öğrencilerden oluşmaktadır. Örneklemlere dâhil edilecek okulların seçiminde sosyoekonomik düzey göz önünde bulundurulmuştur. Şehir merkezinde bulunan okullar ise birinci grubu 
oluştururken, daha çok kırsal özellikler gösteren bölgeye ait okullar ise ikinci grubu oluşturmuştur. Bu okullarda örneklemlerin seçiminden "nicel araştırma yönteminde en sık kullanılagelmiş örnekleme yöntemi” olan seçkisiz (random) yöntem kullanılmıştır (Şimşek ve Ylldırım, 2008:102). Araştırmaya toplamda 256 öğrenci katılmıştır. Bu öğrencilerden 84’ü altıncı sınıf, 85’i yedinci sınıf ve 87’si sekizinci sinıftadır. Bu öğrencilerden 123’ü kız, 133’ü ise erkektir. Birinci grupta 157, ikinci grupta ise 99 öğrenci yer almıştır. Bu gruplar arasında öğrenci sayısında farklılık oluşmasında ikinci grubun bulunduğu okullarda diğer gruba kıyasla daha az sayıda öğrencinin eğitim-öğretim görmesi etkili olmuştur.

\section{Veri toplama araçları}

$\mathrm{Bu}$ araştırmada veri toplama aracı olarak likert tipi dinleme stratejileri ölçeği kullanılmıştır. Ölçeğin geliştirilmesi aşaması şu şekilde olmuştur:

Araştırma amacına yönelik olarak kapalı uçlu sorulardan oluşan soru listesi hazırlanmıştır. Soruların hazırlanmasında alan taraması yapılarak hedeflenen kazanımlara yönelik soru listesi hazırlanmıştır.

Ankette cevaplar Tamamen Katılyorum, Katıliyorum, Kararsızım, Katılmıyorum, Kesinlikle Katılmıyorum biçiminde hazırlanmıştır. Cevapların Spss 17 programında puanlama biçimi Tamamen Kathlyorum-5, Katılyorum-4, Kararsızım-3, Katılmıyorum-2, Kesinlikle Katılmıyorum-1 şeklindedir.

Öncelikli olarak 66 sorudan oluşan soru listesi (anket) 44 öğrenciden oluşan bir gruba ön test olarak uygulanmıştır. Soruların güvenirlik hesabı için Alfa Katsayısı formülü kullanılmıştır. Faktör analizi sonucunda $(0,870)$ etkisiz olduğu görülen maddeler listeden çıkarılmıştır. Bu işlemlerin sonucunda oluşan 50 soruluk listenin alfa katsayısı değeri o,930 olarak belirlenmiştir. "Anketten çıarılan maddelerden sonra güvenirlilik kat sayısının artması, madde değerlendirilmesinde uygun formüllerin kullanıldığına işaret etmektedir.”(Fidan, 2012:43). Uygulanan ankette yer alan sorulardan 15 tanesi öğrencilerin eleştirel dinleme stratejilerini ölçmeye yönelik ifadelerden oluşmaktadır. Ankette yer alan bu maddeler belirlenerek ayrı başlık halinde frekans, yüzdelik oran ve $\mathrm{p}<0,05$ anlamlılık katsayısına göre değerlendirilmiştir.

Soruların kapsam geçerliliğinin belirlenmesinde uzman görüşüne başvurulmuştur. Erciyes Üniversitesi’nde bulunan üç uzmanın görüşleri sonucunda araştırmanın kapsam geçerliliğ̈inin olduğu sonucuna ulaşılmıştır.

$\mathrm{Bu}$ araştırmanın eleştirel dinleme stratejilerini belirlemeye yönelik anket soruları şu şekildedir:

1. Dinleme sırasında öğretmenimle aynı fikirde değilsem, öğretmenime soru sorar ve onu dinlemeye devam ederim.

2. Türkçe öğretmenimiz bir konu hakkında bilgi verirken, konunun ana noktaları üzerinde düşünürüm.

3. Derste dinlediklerimi kendi cümlelerimle anlatabilirim.

4. Dinleme etkinliği sırasında söz alarak, konu hakkındaki düşüncelerimi ifade ederim.

5. Dersin sonunda dinlediğimiz konuları önemliden az önemliye doğru sıralarım.

6. Türkçe öğretmenimizi dinledikten sonra konuyu anladığımdan emin olmak için öğretmenime soru sorarım.

7. Öğretmenimiz bir konuyu anlatırken anladıklarımla daha önceden öğrendiğimiz konuları ilişkilendiririm. 
Examination of critical listening strategies in Turkish lessons of secondary school students in terms of various variables / M. Fidan (p. 79-98)

8. Ders sırasında öğretmenimizi dinlerken, konu hakkındaki düşüncelerimi söylemekte istekliyimdir.

9. Derste öğretmenimizi dinlerken bütün konuları değil diğerlerinden daha çok önemli gördüğüm konuları not alırım.

10. Dinlediğimiz konu ile ilgili sınıfta yapılan tartışmalara görüşlerimle katılırım.

11. Öğretmenimizi dinlerken katılmadığım durumlar olursa, bu durumlara neden katılmadığımı kendi kendime düşünürüm.

12. Ders sırasında başka kişilerin konuşmalarındaki telaffuz ve kelime yanlışlarını düzeltirim.

13. Kullanılan sözlerin ortama, konuşulan kişiye ve amaca göre farklı anlamlarının olabileceğini algllayabilirim.

14. Dinlediklerimizin ana düşüncelerini ve yan düşüncelerini bulabilirim.

15. Dersi dinlerken anlamadığımı düşündüğüm zaman soru sorarak veya başımı yukarı kaldırarak anlamadığımdan öğretmenimizi haberdar ederim.

\section{Verilerin analizi}

Elde edilen verilerin sınıf düzeyi, cinsiyet ve sosyo-ekonomik düzey açısından değerlendirilmesinde likert tipi dinleme stratejileri ölçeği kullanılmıştır. Verilerin değerlendirilmesinde Spss 17 programından faydalanılmıştır. Verilerin cinsiyet yönünden analizinde bağımsız örneklemler t testi, sınıf düzeyi ve sosyo-ekonomik düzey yönünden analizinde ise tek yönlü varyans analizi kullanılmıştır. "Elde edilen veriler tablolar halinde sunulmuştur. Anlaml farklılı oluşturan ( $\mathrm{p}<\mathrm{0,05}$ ) maddelerin değerlendirilmesi yapılmıştır." (Fidan, 2012:52). Bulgular bölümünde bağımsız örneklemler t testi ve anova testi ile elde edilen sonuçlardan anlamlı değişiklik oluşturan maddelere yer verilmiştir. Öğrencilerin eleştirel dinleme stratejilerini kullanma durumlarının belirlenmesinde ise sıklık (f) ve yüzdelik dilim (\%) değerleri dikkate alınmıştır. Tablolarda yer alan değerlerden anlamlı farklılık içerenler $(*)$ işareti ile belirginleştirilmiştir.

\section{Bulgular}

Ortaokul öğrencilerinin Türkçe derslerinde kullandıkları eleştirel dinleme stratejilerinin değerlendirilmesi amacıyla yapılan bu araştırmada eleştirel dinleme stratejileri sınıf düzeyi, cinsiyet ve sosyo-ekonomik düzey değişkenleri yönünden incelenmiştir. Yapılan t testi ve anova testi sonucunda elde edilen veriler incelendiğinde her değişken altında bazı maddelerde anlamlı farklılıkların olduğu görülmüştür. Bu sebeple anlamlı farklılık oluşturan maddeler hakkında detaylı değerlendirmeler yapılmıştır. Öğrencilerin Türkçe derslerinde kullandıkları eleştirel dinleme stratejilerinin belirlenmesinde frekans ve yüzdelik dilim ögeleri kullanılmıştır. Bütün anket maddeleri bu amaçla oransal yönden analiz edilmiştir.

\section{Öğrencilerin kullandıkları eleştirel dinleme stratejileri}

$\mathrm{Bu}$ araştırmada ortaokul öğrencilerinin Türkçe derslerinde kullandıkları eleştirel dinleme stratejileri frekans ve yüzdelik oran yönünden incelenmiştir. Bu incelemeler sonucunda oluşan, öğrencilerin Türkçe derslerinde kullandıkları dinleme stratejilerine dair tablo aşağıda yer almaktadır: 
Tablo 1: Eleştirel Dinleme Stratejileri

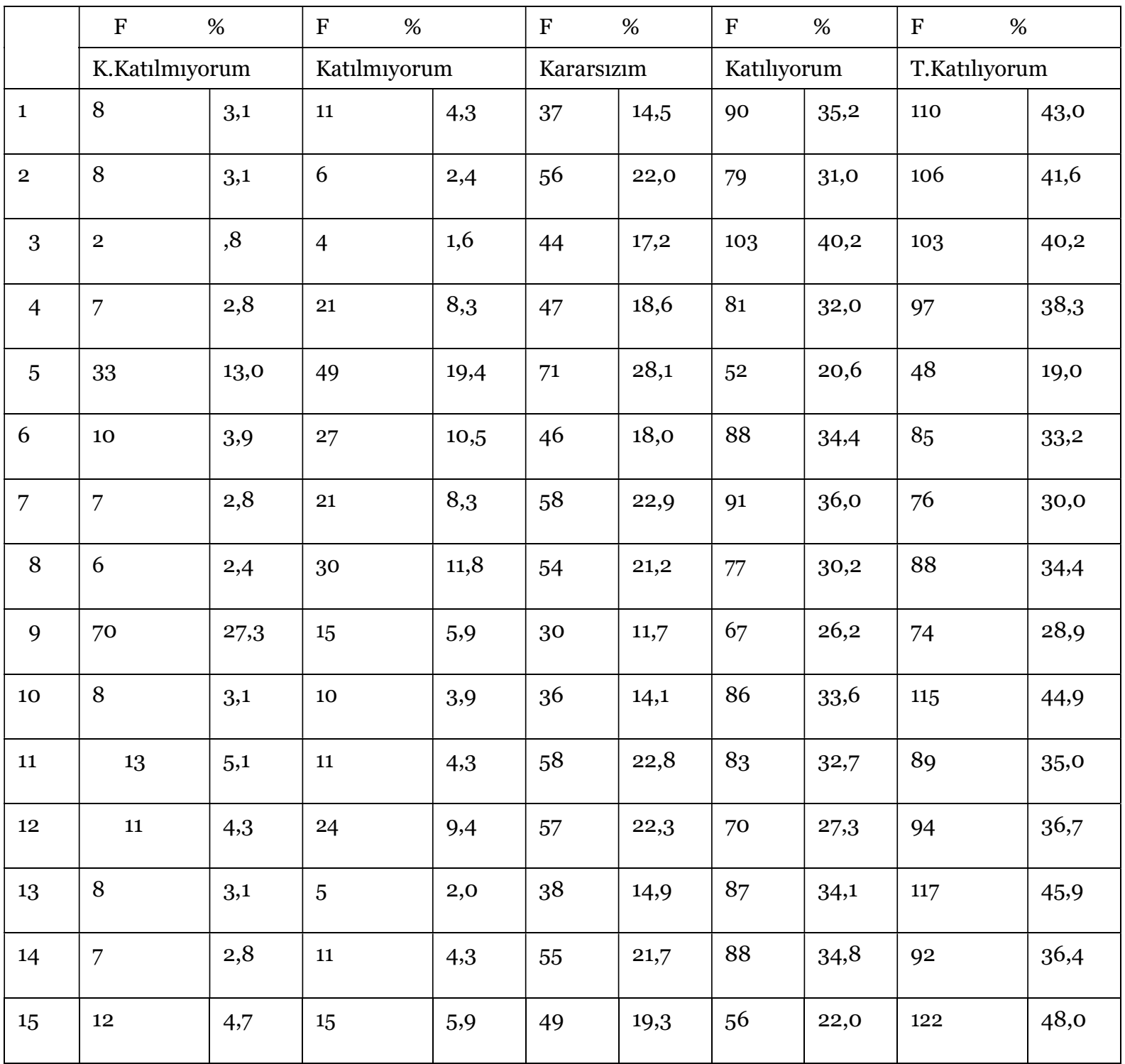

Ankette bulunan "Dinleme strasında öğretmenimle ayn fikirde değilsem, öğretmenime soru sorar ve onu dinlemeye devam ederim." maddesine ait veriler incelendiğinde öğrencilerin \%3,1”i kesinlikle katılmıyorum, \%4,3’ü katılmıyorum, \%14,5’i kararsızım, \%35,2'si katıllyorum ve \%43’ü tamamen katılıyorum şeklinde cevap vermiştir. Eleştirel dinleme becerisi, eleştirel düşünmeyi gerektirmektedir. Öğrencilerin, öğretmenleri ile aynı fikirde olmadıkları durumlarda bunu soru sorarak ifade etmeleri onların dinlediklerini sorguladıklarını ve üst düzey düşünme becerilerini kullandıklarını göstermektedir. Nitekim öğrencilerin \%78,2'sinin bu ifadeye katıldığını belirtmesi onların çoğunluğunun dinleme etkinlikleri sırasında bu eleştirel dinleme stratejisini kullandıklarının göstergesi niteliğindedir.

Ankette bulunan "Türkçe öğretmenimiz bir konu hakkında bilgi verirken, konunun ana noktalar üzerinde düşünürüm.” ifadesi incelendiğinde öğrencilerin \%3,1’i kesinlikle katılmıorum, \%2,4’ü katılmıyorum, \%22'si kararsızım, \%31'i katılıyorum ve \%41,6'sı tamamen katılıyorum şeklinde cevap vermiştir. Öğrencilerin ilgili maddeye \%72,6 oranla katıldıkları görülmektedir. Konunun ana noktaları 
Examination of critical listening strategies in Turkish lessons of secondary school students in terms of various variables / M. Fidan (p. 79-98)

üzerinde düşünme, bireylerin öğrendikleri arasında bağ kurmasını ve kavram haritası oluşturmasını sağlamaktadır. Bu durum eleştirel düşünme basamaklarından biridir. Bu sonuçlara göre öğrencilerin genelinin derslerde bu dinleme stratejilerini kullandıkları söylenilebilir.

“Derste dinlediklerimi kendi cümlelerimle anlatabilirim.” ifadesi incelendiğinde öğrencilerin \%8’i kesinlikle katılmıyorum, \%1,6’sı katılmıyorum, \%17,2'si kararsızım, \%40,2'si katılıyorum ve \%40,2'si tamamen katılıyorum şeklinde cevap vermiştir. Öğrencilerin \%80,2 oranla bu maddedeki ifadeye katılım gösterdikleri görülmektedir. Bu durum öğrencilerin çoğunluğunun dinlediklerini kendi zihin süzgeçlerinden geçirerek ifade ettiklerini göstermektedir.

Öğrencilere uygulanan ankette yer alan "Dinleme etkinliği sırasında söz alarak, konu hakkındaki düşüncelerimi ifade ederim.” ifadesine öğrencilerin \%2,8’i kesinlikle katılmıorum, \%8,3’ü katılmıyorum, \%18,6'sı kararsızım, \%32'si katılıyorum, \%38,3’ü tamamen katılıyorum şeklinde cevap vermiştir. İlgili maddeye öğrencilerin \%70,3 oranla katılmaları, onların genelinin dinleme etkinlikleri sırasında kendi düşüncelerini de ifade edebildiklerini göstermektedir.

"Dersin sonunda dinlediğimiz konuları önemliden az önemliye doğru stralarım.” cümlesi incelendiğinde öğrencilerin \%13,'ü kesinlikle katılmıyorum, \%19,4'ü katılmıyorum, \%28,1’i kararsızım, \%20,6'sı katılıyorum ve \%19'u tamamen katılıyorum şeklinde cevap vermiştir. Öğrencilerin dinledikleri konuları amaca uygunluk ve işlevsellik yönünden önem sırasına koymaları bu süreçte üst bilişsel becerileri kullandıklarını gösterir. Bu sebeple dinlenilen bilgileri önem sırasına koyma eleştirel dinleme becerilerinden biridir. Ancak bu maddeye öğrencilerin \%39,6 oranla katılım gösterdikleri görülmektedir. Bu durum öğrencilerin bu dinleme stratejisini derslerde genel olarak kullanmadıklarını göstermektedir.

Ankette yer alan "Türkçe öğretmenimizi dinledikten sonra konuyu anladığımdan emin olmak için öğretmenime soru sorarım.” maddesine öğrencilerin \%3,9'u kesinlikle katılmıorum, \%10,5’i katılmıyorum, \%18’i kararsızım, \%34,4'ü katılıyorum ve \%33,2'si tamamen katılıyorum şeklinde cevap vermiştir. Katıllyorum ve tamamen katılıyorum şeklinde cevap veren öğrencilerin oranının \%67,6 olduğu görülmektedir. Bu durum öğrencilerin çoğunluğunun bu dinleme stratejisini kullandığını göstermektedir.

Ankette bulunan "Öğretmenimiz bir konuyu anlatırken anladıklartmla daha önceden öğrendiğimiz konuları ilişkilendiririm.” maddesine öğrencilerin \%2,8’i kesinlikle katılmıyorum, \%8,3’ü katılmıyorum, \%22,9'u kararsızım, \%36'sı katılıyorum, \%30'u tamamen katılıyorum cevabını vermiştir. Bu sonuca göre öğrencilerin \%66'sının derslerde dinledikleri konular ile daha önce öğrendiklerini ilişkilendirdiği söylenilebilir.

"Ders sırasında öğretmenimizi dinlerken, konu hakkındaki düşüncelerimi söylemekte istekliyimdir." maddesine öğrencilerin \%2,4'ünün kesinlikle katılmıyorum, \%11,8'inin katılmıyorum, \%21,2'sinin kararsızım, \%30,2'sinin katılıyorum, \%34,5'inin tamamen katılıyorum cevabını verdikleri görülmektedir. Öğrencilerin \%64,7'lik bölümünün katılıyorum cevabını vermesi bu eleştirel dinleme stratejisinin öğrencilerin çoğunluğu tarafından kullanıldığını göstermektedir.

Ankette yer alan "Derste öğretmenimizi dinlerken bütün konuları değil diğerlerinden daha çok önemli gördüğ̈̈m konular not alırm.” maddesine öğrencilerin \%27,3’ü kesinlikle katılmıyorum, \%5,9’u katılmıyorum, \%11,7'si kararsızım, \%26,2'si katılıyorum, \%28,9’u tamamen katılıyorum şeklinde cevap 
vermiştir. Öğrencilerin \%55,1’i bu maddeye katılım göstermiştir. Bu sonuçlara göre öğrencilerin çoğunluğunun bu dinleme stratejisini kullandıklarını söylemek mümkündür.

Öğrencilerin kullandıkları eleştirel dinleme stratejilerini belirlemek amacıyla uygulanan anketteki "Dinlediğimiz konu ile ilgili sımıfta yapılan tartışmalara görüşlerimle katılırım.” ifadesine öğrencilerin \%3,1'i kesinlikle katılmıyorum, \%3,9’u katılmıyorum, \%14,1’i kararsızım, \%33,7'si katılıyorum, \%45,1'i tamamen katılıyorum cevabını vermişlerdir. Öğrencilerin \%78,8’inin katılım gösterdiği bu dinleme stratejisi üst düzey bir eleştirel beceri olmasından dolayı önemli konumdadır. Bu sonuçlara göre öğrencilerin genel olarak bu dinleme stratejisini kullandıkları söylenebilir.

Ankette bulunan "Öğretmenimizi dinlerken katılmadiğım durumlar olursa, bu durumlara neden katılmadiğımı kendi kendime düşünürüm.” ifadesine öğrencilerin \%5,1’i kesinlikle katılmıyorum, \%4,3’ü katılmıyorum, \%22,8’i kararsızım, \%32,7'si katılıyorum, \%35’i tamamen katılıyorum cevabını vermişlerdir. Öğrencilerin \%67,7 oranla bu maddeye katılım göstermeleri onların çoğunluğunun bu dinleme stratejisini kullandığını göstermesi açısından önemlidir. Yukarıda sıralanan sonuçlara göre öğrencilerin bu eleştirel dinleme stratejisini derslerde kullandıkları söylenebilir.

Ankette bulunan "Ders sırasında başka kişilerin konuşmalarındaki telaffuz ve kelime yanlş̧larım düzeltirim.” ifadesine öğrencilerin \%4,3’ü kesinlikle katılmıyorum, \%9,4’ü katılmıyorum, \%22,3’ü kararsızım, \%27,3’ü katılıyorum, \%36,7'si tamamen katılıyorum cevabını vermiştir. Öğrencilerin hem dikkat hem de düşünme becerilerini içeren bu dinleme stratejisine \%64 oranla katılım gösterdikleri görülmektedir. Bu sonuçlara göre öğrencilerin çoğunluğunun bu dinleme stratejisini kullandıkları söylenilebilir.

Ankette bulunan "Kullanılan sözlerin ortama, konuşulan kişiye ve amaca göre farkh anlamlarmın olabileceğini algılayabilirim.” maddesine öğrencilerin \%3,1’i kesinlikle katılmıyorum, \%2'si katılmıyorum, \%14,9'u kararsızım, \%34,1'i katılıyorum, \%45,9'u tamamen katılıyorum şeklinde cevap vermiştir. Öğrencilerin \% 80 oranla katılım gösterdikleri bu maddeye göre kullanılan sözlerin değişkenliğini içeren bu eleştirel dinleme stratejisinin öğrenciler tarafından derslerde kullanıldı̆̆ı söylenebilir.

“Dinlediklerimizin ana düşüncelerini ve yan düşüncelerini bulabilirim.” maddesine öğrencilerin \%2,8'i kesinlikle katılmıyorum, \%4,3'ü katılmıyorum, \%21,7'si kararsızım, \%34,8’i katılıyorum, \%36,4’ü tamamen katıllyorum şeklinde cevap vermiştir. Öğrencilerin dinlediklerini yorumlamalarını ve dinlenilenleri ana fikir, destekleyici fikir bağlamında sınıflandırmalarını içeren bu dinleme stratejisine \%71,2 oranla katıldıkları görülmektedir. Bu sonuçlara göre öğrencilerin ilgili dinleme stratejisini genel olarak kullandıkları söylenebilir.

Ankette bulunan "Dersi dinlerken anlamadiğımı düşündüğüm zaman soru sorarak veya başımı yukarı kaldırarak anlamadığımdan öğretmenimizi haberdar ederim.” maddesine öğrenciler \%4,7 kesinlikle katılmıyorum, \%5,9 katılmıyorum, \%19,3 kararsızım, \%22 katılıyorum, \%48 tamamen katılıyorum oranlarıyla cevap vermiştir. Katılıyorum ve tamamen katılıyorum ifadelerinin tercih edilme oranları toplandığında öğrencilerin \%8o'lik diliminin bu dinleme stratejisini kullandığı söylenilebilir.

\section{Eleştirel dinleme stratejilerinin cinsiyet değişkeni yönünden değerlendirilmesi}

Ortaokul öğrencilerinin Türkçe derslerinde kullandıkları eleştirel dinleme stratejilerinin değerlendirilmesi amacıyla yapılan bu çalışmada, eleştirel dinleme stratejilerinin kullanımında 
88 / RumeliDE Journal of Language and Literature Studies 2019.15 (June)

Examination of critical listening strategies in Turkish lessons of secondary school students in terms of various variables / M. Fidan (p. 79-98)

cinsiyetin etkisi belirlenmeye çalışılmıştır. Bu amaçla bağımsız gruplar t testi yapılmıştır. Elde edilen verilere dair tablo aşağıda yer almaktadır:

Tablo 2: Eleştirel Dinleme Stratejilerinin Cinsiyet Yönünden Değerlendirilmesi

\begin{tabular}{|c|c|c|c|c|c|c|c|}
\hline & $\begin{array}{l}\text { Katılımcı } \\
\text { Öğrencilerin } \\
\text { Cinsiyetleri }\end{array}$ & $\mathrm{N}$ & $\bar{X}$ & $\mathrm{SS}$ & $\mathrm{T}$ & sd & $\mathrm{P}$ \\
\hline \multirow[t]{2}{*}{ 1.Madde } & \multirow{2}{*}{$\begin{array}{l}\text { Kız } \\
\text { Erkek }\end{array}$} & 123 & 4,1870 & ,87168 & 1,243 & \multirow[t]{2}{*}{254} & \multirow[t]{2}{*}{,215 } \\
\hline & & 133 & 4,0301 & 1,12101 & 1,255 & & \\
\hline \multirow[t]{2}{*}{ 2.Madde } & \multirow{2}{*}{$\begin{array}{l}\text { Kız } \\
\text { Erkek }\end{array}$} & 122 & 4,1639 & ,82683 & 1,663 & \multirow[t]{2}{*}{253} & \multirow[t]{2}{*}{,098 } \\
\hline & & 133 & 3,9549 & 1,14060 & 1,685 & & \\
\hline \multirow[t]{2}{*}{ 3.Madde } & \multirow{2}{*}{$\begin{array}{l}\text { Kiz } \\
\text { Erkek }\end{array}$} & 123 & 4,1626 & 84324 &,- 246 & \multirow[t]{2}{*}{254} & \multirow[t]{2}{*}{,806 } \\
\hline & & 133 & 4,1880 & ,80858 &,- 245 & & \\
\hline \multirow[t]{2}{*}{ 4.Madde } & \multirow{2}{*}{$\begin{array}{l}\text { Kiz } \\
\text { Erkek }\end{array}$} & 121 & 4,0248 & 1,06820 & 1,081 & \multirow[t]{2}{*}{251} & \multirow[t]{2}{*}{,281 } \\
\hline & & 132 & 3,8788 & 1,07739 & 1,082 & & \\
\hline \multirow[t]{2}{*}{ 5.Madde } & \multirow{2}{*}{$\begin{array}{l}\text { Kiz } \\
\text { Erkek }\end{array}$} & 123 & 3,1057 & 1,30455 &,- 296 & \multirow[t]{2}{*}{251} & \multirow[t]{2}{*}{, 768} \\
\hline & & 130 & 3,1538 & 1,28474 &,- 296 & & \\
\hline \multirow[t]{2}{*}{ 6.Madde } & \multirow{2}{*}{$\begin{array}{l}\text { Kuz } \\
\text { Erkek }\end{array}$} & 123 & 3,8699 & 1,10853 & ,626 & \multirow[t]{2}{*}{254} & \multirow[t]{2}{*}{, 532} \\
\hline & & 133 & 3,7820 & 1,13710 & ,627 & & \\
\hline \multirow[t]{2}{*}{ 7.Madde } & \multirow{2}{*}{$\begin{array}{l}\text { Kiz } \\
\text { Erkek }\end{array}$} & 121 & 3,8926 & 98996 & 1,031 & \multirow[t]{2}{*}{251} & \multirow[t]{2}{*}{,304 } \\
\hline & & 132 & 3,7576 & 1,08509 & 1,035 & & \\
\hline \multirow[t]{2}{*}{ 8.Madde } & \multirow{2}{*}{$\begin{array}{l}\text { Kiz } \\
\text { Erkek }\end{array}$} & 123 & 3,8374 & 1,08925 & ,139 & 253 & ,890 \\
\hline & & 132 & 3,8182 & 1,11765 & 139 & & \\
\hline 9.Madde & $\mathrm{K} ı \mathrm{Z}$ & 122 & 3,4634 & 1,55391 & 2,235 & 254 & ,026* \\
\hline & Erkek & 132 & 3,0206 & 1,59766 & 2,237 & & \\
\hline 10.Madde & $\mathrm{K} ı \mathrm{z}$ & 122 & 4,2623 & ,87010 & 1,907 & 253 & ,055 \\
\hline & Erkek & 133 & 4,0226 & 1,11101 & 1,926 & & \\
\hline 11.Madde & $\mathrm{Kuz}$ & 122 & 3,9344 & 1,14803 & ,733 & 252 & ,464 \\
\hline & Erkek & 132 & 3,8333 & 1,04966 & ,731 & & \\
\hline 12.Madde & $\mathrm{K} ı \mathrm{Z}$ & 123 & 3,9268 & 1,10268 & 1,320 & 254 & 188 \\
\hline & Erkek & 133 & 3,7368 & 1,19275 & 1,324 & & \\
\hline 13.Madde & $\mathrm{Kuz}$ & 122 & 4,2459 & ,86542 & 1,095 & 253 & ,275 \\
\hline & Erkek & 133 & 4,1128 & 1,05640 & 1,104 & & \\
\hline 14.Madde & $\mathrm{Kız}$ & 121 & 4,0909 & ,86603 & 1,746 & 251 & ,082 \\
\hline & Erkek & 132 & 3,8712 & 1,10795 & 1,765 & & \\
\hline 15.Madde & $\mathrm{K} ı \mathrm{Z}$ & 123 & 4,0976 & 1,13379 & ,934 & 252 &, 351 \\
\hline & Erkek & 131 & 3,9618 & 1,17934 & ,935 & & \\
\hline
\end{tabular}

Not:(*) işaretli maddeler $\mathrm{p}<0,05$ düzeyinde anlamlı olan maddelerdir.

Ankette yer alan "Derste öğretmenimizi dinlerken bütün konularl değil diğerlerinden daha çok önemli gördüğüm konuları not alırım.” maddesi ölçekte yer alan dokuzuncu maddedir. Bu maddeye verilen 
cevaplarda kız öğrencilerin ortalama puanının 3,46, erkek öğrencilerin ortalama puanının ise 3,02 olduğu tespit edilmiştir. İki grubun ortalama puanları arasındaki farkın istatistiksel olarak anlamlı olup olmadığı bağımsız örneklemler için t testi kullanılarak yoklanmıştır. Elde edilen $t$ değerinin $\mathrm{p}<0,05$ düzeyinde anlamlı olduğu görülmüştür. Bu verilere göre kız öğrencilerin dinleme etkinliklerinde önemli görülen noktaları not almaları yönünden erkek öğrencilere göre daha başarılı oldukları söylenilebilir. $(\mathrm{t}=2,23,2,23, \mathrm{p}<0,05)$

\section{Eleştirel dinleme stratejilerinin sınıf değişkeni yönünden değerlendirilmesi}

Tablo 3: Eleştirel Dinleme Stratejilerinin Sinıf Düzeyi Yönünden Değerlendirilmesi

\begin{tabular}{|c|c|c|c|c|c|c|}
\hline & $\begin{array}{l}\text { Katılımcı } \\
\text { Öğrencilerin } \\
\text { Sinıfları }\end{array}$ & $\mathrm{N}$ & $\overline{\mathrm{X}}$ & SS & $\mathrm{F}$ & $\mathrm{p}$ \\
\hline \multirow{4}{*}{ 1.Madde } & \multirow{4}{*}{$\begin{array}{l}\text { 6.Sinif } \\
\text { 7.Sinif } \\
\text { 8.Sinif }\end{array}$} & 84 & 4,3095 & 98147 & \multirow{4}{*}{2,821} & \multirow{4}{*}{,061 } \\
\hline & & 85 & 3,9529 & 1,11169 & & \\
\hline & & 87 & 4,0575 & ,90677 & & \\
\hline & & 256 & 4,1055 & 1,01005 & & \\
\hline \multirow{4}{*}{ 2.Madde } & \multirow{4}{*}{$\begin{array}{l}\text { 6.Sinif } \\
\text { 7.Sinıf } \\
\text { 8.Sinıf }\end{array}$} & 84 & 4,0238 & 1,15097 & \multirow{4}{*}{,165 } & \multirow{4}{*}{,848 } \\
\hline & & 85 & 4,1059 & ,95148 & & \\
\hline & & 86 & 4,0349 & 91327 & & \\
\hline & & 255 & 4,0549 & 1,00634 & & \\
\hline \multirow{4}{*}{ 3.Madde } & \multirow{4}{*}{$\begin{array}{l}\text { 6.Sinif } \\
\text { 7.Sinıf } \\
\text { 8.Sinif }\end{array}$} & 84 & 4,3690 & ,74088 & \multirow{4}{*}{3,678} & \multirow{4}{*}{, $027^{*}$} \\
\hline & & 85 & 4,1176 & ,85093 & & \\
\hline & & 87 & 4,0460 & ,84782 & & \\
\hline & & 256 & 4,1758 & ,82388 & & \\
\hline \multirow{4}{*}{ 4.Madde } & \multirow{4}{*}{$\begin{array}{l}\text { 6.Sinif } \\
\text { 7.Sinif } \\
\text { 8.Sinif }\end{array}$} & 84 & 4,0238 & 1,10831 & \multirow{4}{*}{1,916} & \multirow{4}{*}{,149 } \\
\hline & & 84 & 4,0595 & 1,01020 & & \\
\hline & & 85 & 3,7647 & 1,08723 & & \\
\hline & & 253 & 3,9486 & 1,07336 & & \\
\hline \multirow{4}{*}{ 5.Madde } & \multirow{4}{*}{$\begin{array}{l}\text { 6.Sinif } \\
\text { 7.Sinif } \\
\text { 8.Sinif }\end{array}$} & 82 & 3,2805 & 1,28884 & \multirow{4}{*}{4,350} & \multirow{4}{*}{, $014^{*}$} \\
\hline & & 84 & 3,3214 & 1,30024 & & \\
\hline & & 87 & 2,8046 & 1,23739 & & \\
\hline & & 253 & 3,1304 & 1,29206 & & \\
\hline \multirow{4}{*}{ 6.Madde } & \multirow{4}{*}{$\begin{array}{l}\text { 6.Sinif } \\
\text { 7.Sinif } \\
\text { 8.Sinif }\end{array}$} & 84 & 4,0238 & ,99367 & \multirow{4}{*}{5,981} & \multirow{4}{*}{, $003^{*}$} \\
\hline & & 85 & 3,9647 & 1,05161 & & \\
\hline & & 87 & 3,4943 & 1,23772 & & \\
\hline & & 256 & 3,8242 & 1,12213 & & \\
\hline \multirow{3}{*}{ 7.Madde } & \multirow{3}{*}{$\begin{array}{l}\text { 6.Sinif } \\
\text { 7.Sinıf } \\
\text { 8.Sinıf }\end{array}$} & 84 & 4,0595 & ,86917 & \multirow{3}{*}{3,370} & \multirow{3}{*}{, $036^{*}$} \\
\hline & & 84 & 3,7262 & 1,10149 & & \\
\hline & & 85 & 3,6824 & 1,10423 & & \\
\hline
\end{tabular}


Examination of critical listening strategies in Turkish lessons of secondary school students in terms of various variables / M. Fidan (p. 79-98)

\begin{tabular}{|c|c|c|c|c|c|c|}
\hline & Toplam & 253 & 3,8221 & 1,04083 & & \\
\hline \multirow{4}{*}{ 8.Madde } & \multirow{4}{*}{$\begin{array}{l}\text { 6.Sinif } \\
\text { 7.Sinif } \\
\text { 8.Sinif }\end{array}$} & 84 & 3,9881 & 1,11392 & \multirow{4}{*}{1,673} & \multirow{4}{*}{,190 } \\
\hline & & 84 & 3,6786 & 1,18383 & & \\
\hline & & 87 & 3,8161 & ,99451 & & \\
\hline & & 255 & 3,8275 & 1,10191 & & \\
\hline \multirow{4}{*}{ 9.Madde } & \multirow{4}{*}{$\begin{array}{l}\text { 6.Sinıf } \\
\text { 7.Sinif } \\
\text { 8.Sinıf }\end{array}$} & 84 & 3,3571 & 1,52602 & \multirow{4}{*}{7,307} & \multirow{4}{*}{,oO1* } \\
\hline & & 85 & 2,7294 & 1,67892 & & \\
\hline & & 87 & 3,6092 & 1,44155 & & \\
\hline & & 256 & 3,2344 & 1,58910 & & \\
\hline \multirow{4}{*}{ 10.Madde } & \multirow{4}{*}{$\begin{array}{l}\text { 6.Sinif } \\
\text { 8.Sinif }\end{array}$} & 83 & 4,2530 & ,92187 & \multirow{4}{*}{,860 } & \multirow{4}{*}{,425 } \\
\hline & & 85 & 4,1059 & 1,10220 & & \\
\hline & & 87 & 4,0575 & ,99249 & & \\
\hline & & 255 & 4,1373 & 1,00823 & & \\
\hline \multirow[t]{4}{*}{ 11.Madde } & \multirow{4}{*}{$\begin{array}{l}\text { 6.Sinif } \\
\text { 7.Sinıf } \\
\text { 8.Sinıf }\end{array}$} & 82 & 4,0854 & ,93229 & \multirow{4}{*}{2,379} & \multirow{4}{*}{,095 } \\
\hline & & 85 & 3,8471 & 1,06353 & & \\
\hline & & 87 & 3,7241 & 1,24536 & & \\
\hline & & 254 & 3,8819 & 1,09699 & & \\
\hline \multirow[t]{4}{*}{ 12.Madde } & \multirow{4}{*}{$\begin{array}{l}\text { 6.Sinif } \\
\text { 7.Sinif } \\
\text { 8.Sinif }\end{array}$} & 84 & 3,8929 & 1,16182 & \multirow{4}{*}{, 389} & \multirow{4}{*}{,678 } \\
\hline & & 85 & 3,7412 & 1,25502 & & \\
\hline & & 87 & 3,8506 & 1,04022 & & \\
\hline & & 256 & 3,8281 & 1,15204 & & \\
\hline \multirow[t]{4}{*}{ 13.Madde } & \multirow{4}{*}{$\begin{array}{l}\text { 6.Sinif } \\
\text { 7.Sinıf } \\
\text { 8.Sinif }\end{array}$} & 83 & 4,2771 & ,78575 & \multirow{4}{*}{,704 } & \multirow{4}{*}{,496 } \\
\hline & & 85 & 4,1059 & 1,14459 & & \\
\hline & & 87 & 4,1494 & ,94658 & & \\
\hline & & 255 & 4,1765 & ,97014 & & \\
\hline \multirow[t]{4}{*}{ 14.Madde } & \multirow{4}{*}{$\begin{array}{l}\text { 6.Sinif } \\
\text { 7.Sinıf } \\
\text { 8.Sinif }\end{array}$} & 84 & 3,9881 & 98781 & \multirow{4}{*}{,854 } & \multirow{4}{*}{,427 } \\
\hline & & 84 & 4,0714 & 1,05037 & & \\
\hline & & 85 & 3,8706 & ,97331 & & \\
\hline & & 253 & 3,9763 & 1,00368 & & \\
\hline \multirow[t]{4}{*}{ 15.Madde } & 6.Sinif & 83 & 3,9518 & 1,18840 & & \\
\hline & 7.Sinif & 85 & 4,1412 & 1,19675 & ,635 &, 531 \\
\hline & 8.Sinif & 86 & 3,9884 & 1,09000 & & \\
\hline & Toplam & 254 & 4,0276 & 1,15722 & & \\
\hline
\end{tabular}

Not:(*) işaretli maddeler $\mathrm{p}<0,05$ düzeyinde anlamlı olan maddelerdir.

Tablo 3'te analizi yapılmış olan üçüncü madde "Derste dinlediklerimi kendi cümlelerimle anlatabilirim.” ifadesi şeklinde öğrencilere yöneltilmiştir. Bu maddeye verilen cevapların ortalama 
puanı 6. sınıfta 4,36, 7.sınıfta 4,11, 8. sınıfta ise 4,04 olarak tespit edilmiştir. Bu ortalamalar arasındaki farkın istatistiksel olarak anlamlı olup olmadığı tek yönlü varyans analizi kullanılarak yoklanmıştır. Elde edilen $\mathrm{f}$ değerinin 0,05 düzeyinde anlamlı olduğu görülmüştür. $(\mathrm{f}=1,91, \mathrm{p}<0,05)$. Bu sonuçlara göre 6 . sınıf öğrencilerinin diğer sinıflara göre dinlediklerini kendi cümleleri ile ifade etme yönünden daha başarılı oldukları söylenilebilir.

Tablo 3’te analizi yapılmış olan beşinci madde "Dersin sonunda dinlediğimiz konuları önemliden az önemliye doğru suralarm." ifadesi şeklinde öğrencilere yöneltilmiştir. Bu maddeye verilen cevapların ortalama puanı 6. sinıfta 3,28, 7.sınıfta 3,32, 8. sınıfta ise 2,80 olarak tespit edilmiştir. Bu ortalamalar arasındaki farkın istatistiksel olarak anlamlı olup olmadığı tek yönlü varyans analizi kullanılarak yoklanmıştır. Elde edilen $f$ değerinin 0,05 düzeyinde anlamlı olduğu görülmüş̧ür. ( $f=4,35, p<0,05$ ). $\mathrm{Bu}$ durum altıncı ve yedinci sınıf öğrencilerinin dinlenilenleri önem sırasına koyma yönünden daha başarılı olduklarını göstermektedir.

Tablo 3’te analizi yapılmış olan altıncı madde “Türkçe öğretmenimizi dinledikten sonra konuyu anladiğımdan emin olmak için öğretmenime soru sorarım." ifadesi şeklinde öğrencilere yöneltilmiştir. $\mathrm{Bu}$ maddeye verilen cevapların ortalama puanı 6. sinıfta 4,02, 7.sinifta 3,96, 8. sinifta ise 3,49 olarak tespit edilmiştir. Bu ortalamalar arasındaki farkın istatistiksel olarak anlamlı olup olmadığı tek yönlü varyans analizi kullanılarak yoklanmıştır. Elde edilen f değerinin 0,05 düzeyinde anlamlı olduğu görülmüştür. ( $\mathrm{f}=5,98, \mathrm{p}<0,05)$. Bu sonuçlara göre sekizinci sinıf öğrencileri dinleme etkinliklerindeki anlamadıkları konularda öğretmene soru sorma yönünden diğer sınfflara göre daha az başarı ortalamasına sahiptirler.

Tablo 3'te analizi yapılmış olan yedinci madde “Öğretmenimiz bir konuyu anlattrken anladıklartmla daha önceden öğrendiğimiz konular ilişkilendiririm.” ifadesi şeklinde öğrenciye yöneltilmiştir. Bu maddeye verilen cevapların ortalama puanı 6. sinifta 4,05, 7.sinifta 3,72, 8. sinifta ise 3,68 olarak tespit edilmiştir. Bu ortalamalar arasındaki farkın istatistiksel olarak anlamlı olup olmadığı tek yönlü varyans analizi kullanılarak yoklanmıştır. Elde edilen $\mathrm{f}$ değerinin 0,05 düzeyinde anlamlı olduğu görülmüştür. $(\mathrm{f}=3,37, \mathrm{p}<0,05)$. Bu sonuçlara göre altıncı sınıf öğrencileri dinlenilenlerle ön bilgileri ilişkilendirme açısından diğer sınıflara göre daha başarılıdırlar.

Tablo 3'te analizi yapılmış olan dokuzuncu madde "Derste öğretmenimizi dinlerken bütün konuları değil diğerlerinden daha çok önemli gördüğüm konular not alırm.” ifadesi şeklinde öğrencilere yöneltilmiştir. Bu maddeye verilen cevapların ortalama puanı 6. sinıfta 3,35, 7.sinıfta 2,72, 8. sinffta ise 3,60 olarak tespit edilmiştir. Bu ortalamalar arasındaki farkın istatistiksel olarak anlamlı olup olmadığı tek yönlü varyans analizi kullanılarak yoklanmıştır. Elde edilen $\mathrm{f}$ değerinin 0,05 düzeyinde anlamlı olduğu görülmüştür. ( $\mathrm{f}=7,30, \mathrm{p}<0,05)$. Bu durum sekizinci sinıf öğrencilerinin dinlenilenler içinden önemli noktaları not alma yönünden diğer sınıflara göre daha başarılı olduklarını göstermektedir. 
Examination of critical listening strategies in Turkish lessons of secondary school students in terms of various variables / M. Fidan (p. 79-98)

\section{Eleştirel dinleme stratejilerinin sosyo-ekonomik düzey değişkeni yönünden değerlendirilmesi}

Tablo 4: Eleştirel Dinleme Stratejilerinin Sosyo-Ekonomik Yönden Değerlendirilmesi

\begin{tabular}{|c|c|c|c|c|c|c|}
\hline & $\begin{array}{l}\text { Sosyo Ekonomik } \\
\text { Gruplar }\end{array}$ & $\mathrm{N}$ & $\overline{\mathrm{X}}$ & SS & $\mathrm{F}$ & $\mathrm{P}$ \\
\hline \multirow{3}{*}{ 1.Madde } & \multirow{3}{*}{$\begin{array}{l}\text { 1.Grup } \\
\text { 2.Grup }\end{array}$} & 157 & 4,1274 & 1,02361 & \multirow{3}{*}{,191 } & \multirow{3}{*}{,663 } \\
\hline & & 99 & 4,0707 & ,99234 & & \\
\hline & & 256 & 4,1055 & 1,01005 & & \\
\hline \multirow{3}{*}{ 2.Madde } & \multirow{3}{*}{$\begin{array}{l}\text { 1.Grup } \\
\text { 2.Grup } \\
\text { Toplam }\end{array}$} & 157 & 4,1210 & ,97632 & \multirow{3}{*}{1,769} & \multirow{3}{*}{,185 } \\
\hline & & 98 & 3,9490 & 1,04903 & & \\
\hline & & 255 & 4,0549 & 1,00634 & & \\
\hline \multirow{3}{*}{ 3.Madde } & \multirow{3}{*}{$\begin{array}{l}\text { 1.Grup } \\
\text { 2.Grup } \\
\text { Toplam }\end{array}$} & 157 & 4,1975 & ,81208 & \multirow{3}{*}{, 280} & \multirow{3}{*}{,597 } \\
\hline & & 99 & 4,1414 & ,84528 & & \\
\hline & & 256 & 4,1758 & ,82388 & & \\
\hline \multirow{3}{*}{ 4.Madde } & \multirow{3}{*}{$\begin{array}{l}\text { 1.Grup } \\
\text { 2.Grup }\end{array}$} & 156 & 3,9679 & 1,08610 & \multirow{3}{*}{ 132 } & \multirow{3}{*}{,717 } \\
\hline & & 97 & 3,9175 & 1,05742 & & \\
\hline & & 253 & 3,9486 & 1,07336 & & \\
\hline \multirow[t]{3}{*}{ 5.Madde } & \multirow{3}{*}{$\begin{array}{l}\text { 1.Grup } \\
\text { 2.Grup }\end{array}$} & 155 & 3,1355 & 1,37736 & \multirow{3}{*}{,006 } & \multirow{3}{*}{,938 } \\
\hline & & 98 & 3,1224 & 1,15111 & & \\
\hline & & 253 & 3,1304 & 1,29206 & & \\
\hline \multirow{3}{*}{ 6.Madde } & \multirow{3}{*}{$\begin{array}{l}\text { 1.Grup } \\
\text { 2.Grup }\end{array}$} & 157 & 3,8854 & 1,14337 & \multirow{3}{*}{1,206} & \multirow{3}{*}{,273 } \\
\hline & & 99 & 3,7273 & 1,08626 & & \\
\hline & & 256 & 3,8242 & 1,12213 & & \\
\hline \multirow{3}{*}{ 7.Madde } & \multirow{3}{*}{$\begin{array}{l}\text { 1.Grup } \\
\text { 2.Grup }\end{array}$} & 155 & 3,9161 & 1,03167 & \multirow{3}{*}{3,293} & \multirow{3}{*}{,o71 } \\
\hline & & 98 & 3,6735 & 1,04315 & & \\
\hline & & 253 & 3,8221 & 1,04083 & & \\
\hline \multirow{3}{*}{ 8.Madde } & \multirow{3}{*}{$\begin{array}{l}\text { 1.Grup } \\
\text { 2.Grup }\end{array}$} & 156 & 3,9679 & 1,06207 & & \\
\hline & & 99 & 3,6061 & 1,13226 & 6,678 & ,010* \\
\hline & & 255 & 3,8275 & 1,10191 & & \\
\hline & 1.Grup & 157 & 3,2930 & 1,55358 & & \\
\hline 9.Madde & 2.Grup & 99 & 3,1414 & 1,64757 &, 551 & , 458 \\
\hline & Toplam & 256 & 3,2344 & 1,58910 & & \\
\hline & 1.Grup & 156 & 4,2692 & ,95273 & & \\
\hline 10.Madde & 2.Grup & 99 & 3,9293 & 1,06189 & 7,049 &, $008^{*}$ \\
\hline & Toplam & 255 & 4,1373 & 1,00823 & & \\
\hline
\end{tabular}




\begin{tabular}{|c|c|c|c|c|c|c|}
\hline \multirow{3}{*}{ 11. Madde } & \multirow{3}{*}{$\begin{array}{l}\text { 1.Grup } \\
\text { 2.Grup } \\
\text { Toplam }\end{array}$} & 156 & 3,8462 & 1,14809 & \multirow{3}{*}{,428 } & \multirow{3}{*}{, 514} \\
\hline & & 98 & 3,9388 & 1,01348 & & \\
\hline & & 254 & 3,8819 & 1,09699 & & \\
\hline \multirow{3}{*}{ 12.Madde } & \multirow{3}{*}{$\begin{array}{l}\text { 1.Grup } \\
\text { 2.Grup } \\
\text { Toplam }\end{array}$} & 157 & 3,8790 & 1,09983 & \multirow{3}{*}{,790 } & \multirow{3}{*}{,375 } \\
\hline & & 99 & 3,7475 & 1,23175 & & \\
\hline & & 256 & 3,8281 & 1,15204 & & \\
\hline \multirow{3}{*}{ 13.Madde } & \multirow{3}{*}{$\begin{array}{l}\text { 1.Grup } \\
\text { 2.Grup }\end{array}$} & 156 & 4,2885 & 1,02868 & \multirow{3}{*}{5,448} & \multirow{3}{*}{,020* } \\
\hline & & 99 & 4,0000 & 84515 & & \\
\hline & & 255 & 4,1765 & ,97014 & & \\
\hline \multirow{3}{*}{ 14.Madde } & \multirow{3}{*}{$\begin{array}{l}\text { 1.Grup } \\
\text { 2.Grup }\end{array}$} & 155 & 4,0000 & 1,01290 & \multirow{3}{*}{,223 } & \multirow{3}{*}{ 637 } \\
\hline & & 98 & 3,9388 & 99293 & & \\
\hline & & 253 & 3,9763 & 1,00368 & & \\
\hline \multirow{3}{*}{ 15.Madde } & \multirow{3}{*}{$\begin{array}{l}\text { 1.Grup } \\
\text { 2.Grup }\end{array}$} & 155 & 4,0710 & 1,19038 & \multirow{3}{*}{,559 } & \multirow{3}{*}{,456 } \\
\hline & & 99 & 3,9596 & 1,10582 & & \\
\hline & & 254 & 4,0276 & 1,15722 & & \\
\hline
\end{tabular}

Not: $(*)$ işaretli maddeler $\mathrm{p}<0,05$ düzeyinde anlamlı olan maddelerdir.

"Ders sirasında öğretmenimizi dinlerken, konu hakkındaki düşüncelerimi söylemekte istekliyimdir" ifadesi ölçekte yer alan sekizinci maddedir. Bu maddeye verilen cevaplarda birinci grupta yer alan öğrencilerin ortalama puanı 3,96, ikinci grupta yer alan öğrencilerin ortalama puanı ise 3,60 olarak tespit edilmiştir. Elde edilen sonuçlara göre dinleme etkinliklerinde öğrencilerin düşüncelerini sözlü olarak ifade edebilmeleri açısından gruplar arasında anlamlı farklılığın olduğu söylenilebilir. (f=6,67, p $<0,05)$. Bu sonuçlara göre birinci grupta yer alan öğrenciler dinleme etkinliklerinde düşüncelerini ifade etme yönünden diğer gruba göre daha isteklidirler.

"Ders sırasında öğretmenimizin anlattı̆̆ konuları not alırken, bunları başlıklar halinde yazarım." ifadesi ölçekte yer alan onuncu maddedir. Bu maddeye verilen cevaplarda birinci grupta yer alan öğrencilerin ortalama puanı 4,26, ikinci grupta yer alan öğrencilerin ortalama puanı ise 3,92 olarak tespit edilmiştir. Elde edilen sonuçlara göre dinleme etkinliklerinde öğrencilerin başlıklar halinde not almaları yönünden gruplar arasında anlamlı farklılığın oluştuğu söylenilebilir. ( $f=7,04, p<0,05)$. Dinleme etkinliklerinde başlıklar halinde not alma yönünden birinci grubun diğerlerine göre daha başarılı olduğu görülmektedir.

"Kullanılan sözlerin ortama, konuşulan kişiye ve amaca göre farkh anlamlarmın olabileceğini algılayabilirim." ifadesi ölçekte yer alan on üçüncü maddedir. Bu maddeye verilen cevaplarda birinci grupta yer alan öğrencilerin ortalama puanı 4,28 , ikinci grupta yer alan öğrencilerin ortalama puanı ise 4,0O olarak tespit edilmiştir. Elde edilen sonuçlara göre dinleme etkinliklerinde, öğrencilerin dinledikleri sözlerin manasının kişiye ve amaca göre değişebileceğini fark etmeleri yönünden gruplar arasında anlamlı farklılık oluşmuştur. $(\mathrm{f}=5,44, \mathrm{p}<0,05)$. Bu sonuçlara göre kullanılan sözün değişkenliğini fark edebilme yönünden birinci grupta yer alan öğrencilerin diğerlerine göre daha başarılı oldukları söylenilebilir. 


\section{Sonuç}

Ortaokul öğrencilerinin Türkçe derslerinde kullandıkları eleştirel dinleme stratejilerinin değerlendirilmesi amacıyla yapılan bu çalışmanın sonuçlarını şu şekilde sıralamak mümkündür:

\section{Öğrencilerin kullandıkları eleştirel dinleme stratejilerine ait sonuçlar}

Üst düzey düşünmeyi gerektiren ve öz güven, saygı, empati gibi duygusal becerileri de içeren eleştirel dinleme stratejileri, öğrencilerin gelişim özellikleri bakımından önemli konumda bulunur. Öğrencilerin bu becerileri kullanım durumlarının belirlenmesi geliştirilecek olan eğitim-öğretim programlarında araştırmacılara katkı sağlayacaktır. Bu çalışmanın ortaokul öğrencilerinin Türkçe derslerinde kullandıkları eleştirel dinleme stratejilerinin belirlenmesi aşamasında şu sonuçlara ulaşılmıştır:

Elde edilen verilere göre ortaokul öğrencilerinin genel olarak Türkçe derslerinde eleştirel dinleme stratejilerini kullandıkları sonucuna ulaşılmıştır. (Araştırmada kullanılan ölçeğe öğrencilerin katılyyorum ve tamamen katılıyorum şeklinde verdikleri cevaplar bu yöndeki olumlu ifadeler olarak değerlendirilmiştir.)

1. Öğrencilerin \%78,2'sinin öğretmenle aynı fikirde olmadıkları durumlarda bunu soru sorarak ifade ettikleri,

2. Öğrencilerin \%72,6’sının dinledikleri konuların ana hatları üzerinde düşündükleri,

3. Öğrencilerin \%80,2'sinin üst bilişsel bir düşünme olan dinlenilenleri kendi cümleleri ile ifade edebildiği,

4. Öğrencilerin \%70,3’ünün dinleme etkinlikleri sırasında kendi fikirlerini söz alarak ifade ettikleri,

5. Öğrencilerin \%39,6'sının dinlenilen konuları önem sırasına koyabildikleri,

6. Öğrencilerin \%67,6'sının dinlediği konuları anlayıp anlamadı̆̆ını belirleyebilmek için öğretmenine soru sorduğu,

7. Öğrencilerin \%66'sının dinlenilenler ile ön öğrenmeler arasında bağ kurdukları,

8. Öğrencilerin \%64,7'sinin dinleme etkinliklerinde kendi düşüncelerini söyleme konusunda istekli oldukları,

9. Öğrencilerin \%55,1’inin dinledikleri konulardan daha çok önemli olduğunu düşündükleri konuları not aldıkları,

10. Öğrencilerin \%78,8'inin üst düzey bilişsel bir beceri gerektiren tartışma etkinliklerine katılım gösterdikleri,

11. Öğrencilerin \%67,7'sinin dinledikleri konularda katılmadıkları durumlarının sebebini içsel araçlarla sorguladıkları,

12. Öğrencilerin \%64'ünün bir dikkat becerisi olan telaffuz ve kelime yanlışlarını düzeltme davranışını gösterdikleri,

13. Öğrencilerin \%80'inin kullanılan sözlerin çeşitli şartlara göre değişkenliğinin farkında olduğu,

14. Öğrencilerin \%71,2'sinin dinledikleri konulardaki ana düşünce ve yan düşünceleri bulabildikleri,

15. Öğrencilerin \%8o'lik bölümünün dinleme etkinliklerinde anlamadıkları konular olduğunda bu durumdan öğretmeni soru sorarak veya jest, mimik hareketleri ile haberdar ettikleri sonucuna ulaşılmıştır. 


\section{Eleştirel dinleme stratejilerinin cinsiyet değişkeni yönünden değerlendirilmesine ait sonuçlar}

Eleştirel dinleme stratejilerinin ortaokul öğrencileri tarafindan kullanımının cinsiyet değişkeni yönünden değerlendirilmesi aşamasında sadece bir maddede gruplar arasında anlamlı farklılık oluştuğu sonucuna ulaşılmıştır. Araştırma sürecinde elde edilen verilere göre dinlenilen konulardan önemli görülen bölümleri not alma yönünden kız öğrencilerin, erkek öğrencilere göre daha başarılı oldukları görülmüştür.

\section{Eleştirel dinleme stratejilerinin sınıf değişkeni yönünden değerlendirilmesine ait sonuçlar}

Ortaokul öğrencilerinin Türkçe derslerinde kullandıkları eleştirel dinleme stratejilerinin sınıf düzeyleri yönünden değerlendirilmesi yapıldığında 5 maddede gruplar arasında anlamlı farklılığın oluştuğu sonucuna ulaşılmıştır. Derste dinlenilenleri kendi cümleleri ile ifade etme ve dinlenilenlerle ön öğrenmeler arasında bă̆ kurma yönünden altıncı sınıf öğrencilerinin diğer sınıflara göre daha başarılı oldukları sonucuna ulaşılmıştır. Derste dinlenilenleri önem sırasına koyma, dinlenilen konudan emin olabilmek için öğretmene soru sorma yönünden ise altıncı ve yedinci sınıf öğrencilerinin, sekizinci sınıflara kıyasla daha başarılı oldukları görülmüsştür. Dinlenilen konulardan önemli görülen noktaları not alma yönünden ise sekizinci sınıfların diğer gruplardan daha önde oldukları belirlenmiştir.

\section{Eleştirel dinleme stratejilerinin sosyo-ekonomik düzey yönünden değerlendirilmesine ait sonuçlar}

Ortaokul öğrencilerinin Türkçe derslerinde kullandıkları eleştirel dinleme stratejileri sosyo-ekonomik düzey yönünden değerlendirildiğinde üç maddede gruplar arasında anlamlı farklllığın oluştuğu görülmüştür. Dinleme etkinlikleri sırasında konu hakkındaki düşüncelerini ifade etme, dinlenilenleri başlıklar halinde not alma, kullanılan sözlerin anlamının duruma göre değişebileceği yönlerinden birinci grupta yer alan öğrencilerin, diğer sosyo-ekonomik grupta yer alan öğrencilere göre daha başarılı oldukları sonucuna ulaşılmıştır.

\section{Tartışma}

Eleştiriyi TDK, "Bir insanı, bir eseri, bir konuyu doğru ve yanlış yanlarını bulup göstermek amacıyla inceleme işi, tenkit” şeklinde tanımlar. Eleştiri becerisinin gelişimi etkili bir dinleyici olmayı da gerektirmektedir. Bu sebeple eleştirel dinleme stratejileri içerdiği duygusal ve zihinsel süreçlerden dolayı çok boyutlu bir yapıda bulunur. Ortaokul öğrencilerinin Türkçe derslerinde kullandıkları eleştirel dinleme stratejilerinin değerlendirilmesi yapıldığında bazı hususların ön plana çıtığı görülmektedir. Bunlardan ilki araştırma ölçeğinin beşinci maddesinde "Dersin sonunda dinlediğimiz konuları önemliden az önemliye doğru stralartm.” şeklinde ifade edilen, dinlenilenleri önem sırasına koyma stratejisidir. Diğer maddelere oranla bu maddenin ortalamasında $(\% 39,6)$ belirgin bir düşüşün olduğu görülmektedir. Dinlenilenleri önem sırasına koyabilme üst bilişsel bir beceri olarak görülmektedir. Nitekim Maden (2013:27), önem sırasına koymayı temel dil becerilerinin geliştirilmesinde öğretimsel bir taktik olarak değerlendirir. Kemiksiz (2015:315) araştırmasında eleştirel dinlemeyi öğrenen bireylerde üst düzey bilişsel düşünme yöntemleri olan "ölçme, değerlendirme, karşlaştırma, çlkarım yapma, yorumlama ve tahmin etmenin” de gelişeceği sonucuna ulaşır. Bu becerilerin eğitim öğretim süreçlerine aktarılmasıyla ilgili olarak Katrancı (2012:133-134) da üst biliş stratejilerinin dinleme 
Examination of critical listening strategies in Turkish lessons of secondary school students in terms of various variables / M. Fidan (p. 79-98)

eğitiminde kullanılmasının öğrencilerin bilgilendirici, öyküleyici gibi farklı metin türlerindeki anlama becerilerini olumlu yönde etkilendiğini, bu durumun anlama farkındalı̆̆ını da geliştirdiğini ifade eder. $\mathrm{Bu}$ durum bir üst bilişsel strateji olan eleştirel dinlemenin eğitsel uygulamalarda kullanılmasının gerekliliğini ortaya koymaktadır.

Bu çalışmada dinlenilen konuların not alınması yönünden kız öğrencilerin daha başarılı oldukları görülmüştür. Bu sonuçlarla uyumlu olarak Çetingöz (2006:121) araştırmasında, not alma stratejisinin öğretiminin kız öğrencilerin başarısının geliştirilmesinde daha etkili olduğunu tespit eder. Öğrenci grupları arasında dinlenilenleri not alma stratejisi yönünden anlamlı farklılığın oluşmasında kız öğrencilerin bu tür uygulamaları yapmakta daha istekli olmalarının etkisinin olduğu düşünülmektedir.

Araştırmada altıncı sınıf öğrencilerinin genel olarak eleştirel dinleme stratejilerini kullanma yönünden diğer sınıflara göre daha başarılı oldukları görülmüştür. Koç ve Arslan (2017:763-764) ortaokul öğrencilerine yönelik araştırmasında ergenlik gibi bazı gelişimsel etkilerin öğrencilerin akademik öz yeterliliklerini etkilediği sonucuna ulaşırlar. Koç ve Arslan (2017:763-764) araştırmalarında ortaokulların en küçük yaş grubunu oluşturan 5. sınıf öğrencilerinin diğerlerine göre akademik öz yeterlik algısı vb. yönlerden daha başarılı olduklarını tespit ederler. Bu araştırmanın da en küçük yaş grubunun 6. sınıf öğrencileri olduğu düşünüldüğünde (araştırmanın yapıldığı dönemde ortaokullar 6,7,8. sınıflardan oluşmaktadır), gruplar arasındaki farklılığının sebebini bu nedene dayandırmak mümkündür. Ancak dinlenilen konulardan önemli görülen noktaları not alma yönünden sekizinci sınıf öğrencilerinin diğer sınıf düzeylerindeki öğrencilerden daha başarılı oldukları görülmektedir. Bu dinleme stratejisinde yedinci sınıfların en düşük ortalamaya sahip olmaları not alma stratejileri ile sınıf düzeyi arasında doğru orantının olmadığını göstermektedir. Bu nedenle eleştirel dinleme stratejileri gibi, üst bilişsel ve duygusal becerilerin kazanılmasına etki eden faktörlere yönelik yeni çalışmaların yapılması, sorunun kaynağına ulaşılması açısından araştırmacılara katkı sağlayacaktır.

Eleştirel dinleme becerilerinin sosyo-ekonomik düzey değişkeni açısından değerlendirilmesi yapıldığında birinci grupta (üst sosyo-ekonomik grup) bulunan öğrencilerin -bütün eleştirel dinleme stratejilerinde benzer durum olmaması kaydıyla- konu hakkındaki düşüncelerini ifade etme, dinlenilenleri başlıklar halinde not alma, kullanılan sözlerin anlamının duruma göre değişebileceği konularında diğer gruba göre daha başarılı oldukları sonucuna ulaşılmıştır. Bu sonuçlarla benzer olarak Şahin (2011:184) de araştırmasında sosyo-ekonomik düzeyin öğrencilerin dinleme becerisi farkındalık durumları üzerinde etkisinin olduğunu tespit eder. Araştırmacı ayrıca sosyo-ekonomik düzey düştükçe bazı dinlemeyle ilgili algılarda da düşüşün olduğunu belirtir. Bu durum sosyo-ekonomik düzeyin öğrencilerin eleştirel dinleme stratejilerini etkileyebileceğini göstermesi açısından önemli konumda bulunmaktadır.

\section{Öneriler}

Sınıf düzeyinin yalnızca dinleme stratejilerine etkisini inceleyen çalışmalar bulunmaktadır. Bu sebeple diğer dil becerilerinin de akademik başarıya etkisinin bulunup bulunmadığına yönelik sınıf düzeyini temel alan çalışmaların yapılması önerilmektedir.

Not alma stratejilerinin kullanımında cinsiyet değişkenin etkisinin varlığı bu araştırma ile ortaya konmuştur. Araştırmacıların bu farklılı̆̆ının oluşmasının nedenleri hakkında çalışmalar yapmalarının geliştirilecek eğitim-öğretim programlarına olumlu yönde katkısı olacağı düşünülmektedir. 


\section{Kaynakça}

Aktaş, Ş., Gündüz, O. (2017). Yazılı ve Sözlü Anlatım. Ankara: Akçă̆ Yayınları.

Akyol, H. (2014). Programa Uygun Türkçe Öğretim Yöntemleri. Ankara: Pegem Akademi.

Cüceloğlu, D. (2010). İnsan ve davranışı. İstanbul: Remzi Kitabevi.

Çetingöz, D. (2006). Not alma stratejisinin öğretimi tarih başarısı, hatırda tutma ve başarı güdüsü. Yayımlanmamış doktora tezi, Dokuz Eylül Üniversitesi Eğitim Bilimleri Enstitüsü, İzmir.

Doğan, Y. (2008), "İlköğretim yedinci sınıf öğrencilerinin dinleme becerisini geliştirmede etkinlik temelli çalışmaların etkililiği”, Türk Eğitim Bilimleri Dergisi, 6(2), 261-286.

Doğan, Y. (2012). Dinleme eğitimi. Ankara: Pegem Akademi.

Doğan, Y., Özçakmak H. (2014). Dinleme becerisinin eğitimi üzerine yapılan lisansüstü tezlerin değerlendirilmesi. Ana Dili Eğitimi Dergisi, 2(2), 90-99.

Epçaçan, C. (2013), “Temel bir dil becerisi olarak dinleme ve dinleme eğitimi”, Adıyaman Üniversitesi Sosyal Bilimler Enstitüsü Dergisi, 11, 331-352.

Fidan, M. (2012). İlköğretim ikinci kademe öğrencilerinin Türkçe dersinde kullandıkları dinleme stratejilerinin değerlendirilmesi. Yayımlanmamış yüksek lisans tezi, Erciyes Üniversitesi Eğitim Bilimleri Enstitüsü, Kayseri.

Gürel, E., Tat, M. (2012). Bir iletişim edimi olarak dinleme ve Türkçede bulunan dinleme temalı atasözleri ile deyimler üzerine bir içerik analizi. Uluslararası Sosyal Araştırmalar Dergisi, 5 (23), 276-297.

Gücüyeter, B. (2009), Türk dili ve edebiyatı derslerinde dinleme eğitimi, Atatürk Üniversitesi Sosyal Bilimler Enstitüsü Dergisi, 13(2), 161-170.

Katrancı, M. (2012). Üstbiliş stratejileri öğretiminin dinlediğini anlama becerisine ve dinlemeye yönelik tutuma etkisi. Yayımlanmamış doktora tezi. Hacettepe Üniversitesi Sosyal Bilimler Enstitüsü, Ankara.

Katrancı, M., Yangın, B. (2013). Üstbiliş stratejileri öğretiminin dinlediğini anlama becerisine ve dinlemeye yönelik tutuma etkisi. Adıyaman Üniversitesi Sosyal Bilimler Enstitüsü Dergisi, 6(11), 733-771.

Kemiksiz, Ö. (2015). Türkçe öğretiminde eleştirel dinleme. Erzincan Üniversitesi Sosyal Bilimler Enstitüsü Dergisi, II, 299-316

Koç, C., Arslan A. (2017). Ortaokul öğrencilerinin akademik öz yeterlik algıları ve okuma stratejileri bilişüstü farkındalıkları. YYÜ Eğitim Fakültesi Dergisi, 14(1), 745-778.

Kurudayığlu, M.; Kana, F. (2013), Türkçe öğretmeni adaylarının dinleme becerisi ve dinleme eğitimi özyeterlik algıları, Mersin Üniversitesi Ë̆itim Fakültesi Dergisi, 9(2), 245-258.

Maden, S. (2013). Temel Dil Becerileri Eğitiminde Kullanılabilecek Aktif Öğrenme Öğretimsel İş/Taktikleri. Ana Dili Eğitimi Dergisi, 1(2), 20-35.

MEB. (2018). Türkçe dersi öğretim programı. Ankara: MEB.

Melanlıŏ̆lu, D. (2012). Dinleme becerisine yönelik ölçme değerlendirme çalışmalarında üstbiliş stratejilerinin kullanımı. Turkish Studies, 7(1), 1583-1595.

TDK (2019). Eleştiri. 10.03.2019 tarihinde http://www.tdk.gov.tr/index.php?option=com_gts\&arama=gts\&guid=TDK.GTS.5c9odfd1bf3f9 8.17405227 adresinden alınmıștır.

Sever, S. (2011). Türkçe öğretimi ve tam öğrenme. Ankara: Anı Yayıncılık.

Şahin, A. (2011). İlköğretim 6. Sınıf Öğrencilerinin Dinleme Becerisi Farkındalıklarının SosyoEkonomik Düzeye Göre İncelenmesi, Çankırı Karatekin Üniversitesi Sosyal Bilimler Enstitüsü Dergisi, 2(1), 178-188. 
Examination of critical listening strategies in Turkish lessons of secondary school students in terms of various variables / M. Fidan (p. 79-98)

Şimşek, H.; Yıldırım, A. (2008). Sosyal bilimlerde nitel araştırma yöntemleri. Ankara: Seçkin Yayınları. Umagan, S. (2007). Dinleme Eğitimi, Kırkkılıç A., Akyol, H. (Ed.), İlköğretimde Türkçe Öğretimi içinde (149-163). Ankara: Pegema Yayıncllı.

Yılmaz, D. (2007). Türkçe Öğretiminde Dinleme Becerisini Geliştirmeye Yönelik Önerilen Etkinliklerin Değerlendirilmesi. Yayımlanmamış Yüksek Lisans Tezi. Niğde Üniversitesi Sosyal Bilimler Enstitüsü Türkçe Eğitimi Ana Bilim Dalı. Niğde. 